\title{
Enhanced Production of Palmarumycins C12 and C13 in Mycelial Liquid Culture of the Endophytic Fungus Berkleasmium sp. Dzf12 with In situ Macroporous Resin Adsorption
}

\author{
Yan Mou, Jing Li, Kaiyi Zhou, Ruiting Yu, Dan Xu, Haiyu Luo, Daiwan Lai and \\ Ligang Zhou* \\ MOA Key Laboratory of Plant Pathology, Department of Plant Pathology, College of Agronomy and Biotechnology, China \\ Agricultural University, Beijing 100193, China \\ *For correspondence: Email: Igzhou@cau.edu.cn; Tel: +86-10-62731199; Fax: +86-10-62731062
}

Received: 28 November 2014

Revised accepted: 23 February 2015

\begin{abstract}
Purpose: To evaluate in situ macroporous resin adsorption for enhancement of palmarumycins $C_{12}$ and $C_{13}$ production in mycelial liquid culture of the endophytic fungus Berkleasmium sp. Dzf12. Methods: Ten macroporous adsorption resins (D-101, D1300, HPD-100, X-5, AB-8, DM130, ADS-17, $D A-201, N K A-9$ and S-8) were tested for absorption of palmarumycins $C_{12}$ and $C_{13}$ in mycelial liquid culture of the endophytic fungus Berkleasmium sp. Dzf12.

Results: Among the resins, DA-201 showed the most significant enhancing effect on accumulation of palmarumycins $C_{12}$ and $C_{13}$ in mycelial liquid culture of endophytic fungus Berkleasmium sp. Dzf12. When resin DA-201 was applied to the medium at a concentration of $4.17 \%$ on day 11 and then harvested on day 15, the maximal yield of palmarumycins $C_{12}$ and $C_{13}$ was 149.86 and $55.78 \mathrm{mg} / \mathrm{L}$, which correspond to 70.69- and 1.82-fold higher than for control (2.12 and $30.70 \mathrm{mg} / \mathrm{L}$, respectively). Approximately $95.81 \%$ of palmarumycin $C_{12}$ and $87.20 \%$ of palmarumycin $C_{13}$ were distributed in resin DA-201.

Conclusion: The results indicate that in situ resin adsorption is an effective strategy for enhancing the production of palmarumycins $C_{12}$ and $C_{13}$, and also for facilitating their recovery from the mycelial liquid culture of Berkleasmium sp. Dzf12.
\end{abstract}

Keywords: Endophytic fungus, Berkleasmium sp. Dzf12, Spirobisnaphthalene, Palmarumycin, Macroporous adsorption resins, Mycelial liquid culture

Tropical Journal of Pharmaceutical Research is indexed by Science Citation Index (SciSearch), Scopus, International Pharmaceutical Abstract, Chemical Abstracts, Embase, Index Copernicus, EBSCO, African Index Medicus, JournalSeek, Journal Citation Reports/Science Edition, Directory of Open Access Journals (DOAJ), African Journal Online, Bioline International, Open-J-Gate and Pharmacy Abstracts

\section{INTRODUCTION}

Endophytic fungi are a special group of microorganisms which spend the whole or part of their lifecycle colonizing inter- and/or intracellularly healthy tissues of the host plant, typically causing no apparent symptoms of disease [1]. They are novel and rich sources of bioactive natural products [2]. Secondary metabolites such as alkaloids, steroids, phenolics, terpenoids and peptides produced by the endophytes have recently received growing interest from the pharmaceutical industry $[3,4]$. Spirobisnaphthalenes are a group of naphthoquinone derivatives, consisting of $1,8-$ dihydroxynaphthalene-derived spiroketal units linked to a second oxidized naphthalene moiety, that show a great variety of biological activities 
such as anti-tumor, anti-bacterial, anti-fungal, anti-leishmanial and enzyme-inhibitory properties [5].

In our previous study, an endophytic fungus isolated from the healthy rhizomes of the medicinal plant Dioscorea zingiberensis was identified as Berkleasmium sp. Dzf12 from which 22 bioactive spirobisnaphthalenes have been successfully obtained [6,7]. Among them, palmarumycins $C_{12}$ and $C_{13}$ were found to be the predominant components. Furthermore, these two compounds could be secreted to the extracellular in liquid culture of Berkleasmium sp. Dzf12. Palmarumycins $\mathrm{C}_{12}$ and $\mathrm{C}_{13}$, which exhibit antibacterial, antifungal and anti-tumor activities as well as inhibitory activity on phospholipase $D$ (PLD), have been isolated from other fungi such as Coniothyrium sp., Cladosporium chlorocephalum and Nattrassia mangiferae, [812]. With the aim of speeding up application of palmarumycins $\mathrm{C}_{12}$ and $\mathrm{C}_{13}$, considerable efforts have been directed at seeking strategies for improving palmarumycins $\mathrm{C}_{12}$ and $\mathrm{C}_{13}$ production in liquid culture of Berkleasmium sp. Dzf12. The strategies include optimization of medium and culture conditions [13], utilization of two-phase culture systems [14], application of oligosaccharides and polysaccharides from its host plant Dioscorea zingiberensis $[15,16]$, and addition of metal ions [17].

The purpose of this study was to investigate the effects of different types of macro porous adsorption resins including D-101, D1300, HPD100, X-5, AB-8, DM130, ADS-17, DA-201, NKA-9 and S-8 on palmarumycins $C_{12}$ and $C_{13}$ production in liquid culture of the endophytic fungus, Berkleasmium sp. Dzf12.

\section{EXPERIMENTAL}

\section{Endophytic fungus and culture conditions}

The endophytic fungus, Berkleasmium sp. Dzf12 (GenBank accession number EU543255), was isolated from the healthy rhizomes of the medicinal plant, Dioscorea zingiberensis C. $\mathrm{H}$. Wright (Dioscoreaceae) in our previous study [6]. It was sub-cultured on potato dextrose agar (PDA) slants at $25{ }^{\circ} \mathrm{C}$ in darkness. For preparation of the inoculum, four disks (about 5 $\mathrm{mm}$ ) with fungal cultures were transferred into each 300-mL Erlenmeyer flask containing 100 $\mathrm{mL}$ of potato dextrose broth (PDB). The flasks were placed on a rotary shaker at $150 \mathrm{rpm}$ and $25{ }^{\circ} \mathrm{C}$ in darkness for 4 days. For fermentation culture, the seed suspension cultures in $3 \%(\mathrm{v} / \mathrm{v})$ were inoculated in each 150-mL Erlenmeyer flasks containing $30 \mathrm{~mL}$ of fermentation medium, which was composed of glucose $40 \mathrm{~g} / \mathrm{L}$, peptone $10 \mathrm{~g} / \mathrm{L}, \mathrm{KH}_{2} \mathrm{PO}_{4} 1.0 \mathrm{~g} / \mathrm{L}, \mathrm{MgSO}_{4} \cdot 7 \mathrm{H}_{2} \mathrm{O} 0.5 \mathrm{~g} / \mathrm{L}$ and $\mathrm{FeSO}_{4} \cdot 7 \mathrm{H}_{2} \mathrm{O} 0.05 \mathrm{~g} / \mathrm{L}$. The fermentation cultures were also conducted on the rotary shaker at $150 \mathrm{rpm}$ and $25^{\circ} \mathrm{C}$ in darkness. Prior to autoclaving at $121^{\circ} \mathrm{C}$ for $20 \mathrm{~min}$, the $\mathrm{pH}$ of the medium was adjusted to 6.5 .

\section{Macroporous adsorption reins}

Ten non-ionic polystyrene resins (D-101, D1300, HPD-100, X-5, AB-8, DM130, ADS-17, DA-201, NKA-9 and S-8) were purchased from Tianjin Haiguang Chemical Company of China (Tianjin, China). They were initially examined as the adsorbents for in situ adsorption of palmarumycins $\mathrm{C}_{12}$ and $\mathrm{C}_{13}$ in mycelial liquid culture of Berkleasmium sp. Dzf12. Their chemical and physical properties, including polarity, particle size, surface area, pore diameter and moisture content are shown in Table 1. Prior to use, the resins were in turn soaked in methanol for $24 \mathrm{~h}$, washed thoroughly with distilled water for 3 - 5 times, immersed in 1 $\mathrm{mol} / \mathrm{L} \mathrm{NaOH}$ solution for $12 \mathrm{~h}$, rinsed by distilled water for 3 - 5 times, immersed in $1 \mathrm{~mol} / \mathrm{L} \mathrm{HCl}$ solution for $12 \mathrm{~h}$, and rinsed with distilled water 3 - 5 times. Each resin was then dried in an oven at $35-40{ }^{\circ} \mathrm{C}$ to a constant dry weight (dw). The moisture $(\%)=\left[\left(\mathrm{W}_{1}-\mathrm{W}_{2}\right) \mathrm{W}_{1}\right] \times 100$, where $\mathrm{W}_{1}$ is the weight prior to drying, $W_{2}$ is the weight after drying.

\section{In situ adsorption culture}

The pre-treated dried resin was wrapped with 30 $\mu \mathrm{m}$-pore nylon cloth (Yanpai Chemical Company, Shanghai, China) into small bags of $0.50-2.00 \mathrm{~g}$ dry weight (dw). The resin bags were suspended in distilled water and autoclaved at $121^{\circ} \mathrm{C}$ for 20 min before being added to the culture broth at the designated time. For screening the optimal resin from the 10 candidates, $1.5 \mathrm{~g}$ of each resin in a nylon bag was added to the mycelial culture flask (30 mL medium in 150-mL flask) on day 9 of culture, so the corresponding concentration of resin in the medium was $5.0 \%(\mathrm{~g} / \mathrm{mL})$. The cultures were harvested on day 15 . For determining the suitable concentration of the selected resin DA-201, different quantities $(0$, $0.50,0.75,1.00,1.25,1.50,1.75$ and $2.00 \mathrm{~g}$ ) of resin DA-201 were added in $30 \mathrm{~mL}$ medium (their corresponding concentrations were $0-6.67 \%$, $\mathrm{g} / \mathrm{mL}$ ) on day 9 of culture. The cultures were harvested on day 15. For obtaining the optimal addition and incubation time of resin DA-201, $4.17 \%$ (1.25 g in $30 \mathrm{~mL}$ medium) of resin was 
Table 1: Chemical and physical properties of the macroporous resins employed

\begin{tabular}{|c|c|c|c|c|c|}
\hline Resin & Polarity & $\begin{array}{l}\text { Particle } \\
\text { size } \\
(\mathrm{mm}) \\
\end{array}$ & $\begin{array}{c}\text { Surface } \\
\text { area }\left(\mathrm{m}^{2} / \mathrm{g}\right)\end{array}$ & $\begin{array}{l}\text { Average pore } \\
\text { diameter } \\
(\mathrm{nm})\end{array}$ & $\begin{array}{c}\text { Moisture } \\
\text { content } \\
(\%)\end{array}$ \\
\hline D-101 & Non-polar & $0.30-1.25$ & $480-530$ & $9-11$ & $67.89 \pm 0.27$ \\
\hline D1300 & Non-polar & $0.30-1.25$ & $\geq 600$ & $9-10$ & $68.27 \pm 0.57$ \\
\hline HPD-100 & Non-polar & $0.30-1.25$ & $\geq 650$ & $8-9$ & $68.39 \pm 0.48$ \\
\hline$X-5$ & Non-polar & $0.30-1.25$ & $500-600$ & $29-30$ & $50.13 \pm 0.17$ \\
\hline AB-8 & Weak-polar & $0.30-1.25$ & $480-520$ & $13-4$ & $68.33 \pm 0.61$ \\
\hline DM130 & Weak-polar & $0.30-1.25$ & $500-550$ & $9-10$ & $66.00 \pm 0.32$ \\
\hline ADS-17 & Middle-polar & $0.30-1.25$ & $90-150$ & $25-30$ & $55.16 \pm 1.09$ \\
\hline DA-201 & Polar & $0.30-1.25$ & $\geq 200$ & $10-13$ & $70.64 \pm 0.52$ \\
\hline NKA-9 & Polar & $0.30-1.25$ & $250-290$ & $15.5-16.5$ & $70.22 \pm 0.23$ \\
\hline S-8 & Polar & $0.30-1.25$ & 100-200 & $28-30$ & $67.12 \pm 0.35$ \\
\hline
\end{tabular}

Note: The information was provided by the manufacturers, except for the moisture content

added into the medium on days $0,3,6,9,10,11$ and 12 of culture, respectively, and the cultures were harvested on day 15. All treatments were performed in triplicate.

\section{Determination of biomass palmarumycins $\mathrm{C}_{12}$ and $\mathrm{C}_{13}$ yield}

The mycelia were harvested by vacuum filtration via a Buchner funnel with a pre-weighed filter paper, and the filtrate volume was measured. The harvested mycelia were washed with deionized water three times to remove medium components, and then dried in an oven at $50-$ $55{ }^{\circ} \mathrm{C}$ to a constant dry weight (dw). Palmarumycins extraction and determination were carried out as previously described [17]. For analysis of palmarumycins $\mathrm{C}_{12}$ and $\mathrm{C}_{13}$ yield in mycelia, $50.0 \mathrm{mg}$ of dry mycelial powder, was deposited in a vial with $5 \mathrm{~mL}$ of methanolchloroform $(9: 1, v / v)$, and then subjected to ultrasonic treatment (three times, 60 min each). After removal of the solid by filtration, the filtrate was evaporated to dryness and re-dissolved in 1 $\mathrm{mL}$ of methanol. For analysis of palmarumycins $\mathrm{C}_{12}$ and $\mathrm{C}_{13}$ in broth, $3 \mathrm{~mL}$ of the culture broth without mycelia was evaporated to dryness and extracted with $5 \mathrm{~mL}$ of methanol-chloroform (9:1, $\mathrm{v} / \mathrm{v}$ ) in an ultrasonic bath, and the liquid extract was then evaporated to dryness and re-dissolved in $1 \mathrm{~mL}$ of methanol. For analysis of palmarumycins $\mathrm{C}_{12}$ and $\mathrm{C}_{13}$ in the resins, the nylon cloth sachet with whole resin was extracted with $30 \mathrm{~mL}$ of methanol-chloroform $(9: 1, \mathrm{v} / \mathrm{v})$. The extraction was repeated until the final extract was colorless. After removal of the resin by filtration, the filtrate was evaporated to dryness and redissolved in $30 \mathrm{~mL}$ of methanol.

Palmarumycins $\mathrm{C}_{12}$ and $\mathrm{C}_{13}$ standards were isolated and identified from the fermentation cultures of the endophytic fungus Berkleasmium sp. Dzf12 in our previous studies [7,15]. Palmarumycins $C_{12}$ and $C_{13}$ yields were analyzed by high performance liquid chromatography
(HPLC) (Shimadzu, Japan), which consisted of two LC-20AT solvent delivery units, an SIL-20A autosampler, an SPD-M20A photodiode array detector, and CBM-20Alite system controller (Shimadzu, Kyoto, Japan), and a reversed-phase Ultimate TM XB C18 column $(4.6 \times 250 \mathrm{~mm}, 5$ $\mu \mathrm{m}$, Welch Materials, Inc., Ellicott, MD, USA). The HPLC column was isocratically eluted with $\mathrm{MeOH}-\mathrm{H}_{2} \mathrm{O}(50: 50, \mathrm{v} / \mathrm{v})$ in 20 min at a flow rate of $1.0 \mathrm{~mL} / \mathrm{min}$. The temperature was maintained at $40{ }^{\circ} \mathrm{C}$, and UV detection at $226 \mathrm{~nm}$. The sample injection volume was $10 \mu \mathrm{L}$. The LCsolution multi-PDA workstation was employed to acquire and process chromatographic data. Palmarumycins $\mathrm{C}_{12}$ and $\mathrm{C}_{13}$ were detected and quantified with the standards. The regression equation of palmarumycin $C_{12}$ was $Y=121295.5$ $X+175236.8(R=0.9997)$, and that of palmarumycin $\mathrm{C}_{13}$ was $\mathrm{Y}=121362.5 \mathrm{X}+$ $256167.5(R=0.9997)$, where $Y$ is the peak area, $X$ is quality $(\mu \mathrm{g})$ of the sample injected each time, and $\mathrm{R}$ the correlation coefficient.

\section{Statistical analysis}

All experiments were carried out in triplicate, and the results are presented as mean \pm standard deviations (SD). The data were subjected to analysis of variance (one-way ANOVA) to detect significant differences using Proc Anova SAS version 8.2. Significance difference was set at $p$ $\leq 0.05$.

\section{RESULTS}

\section{Optimized macroporous resins}

The effect of the resins on mycelia biomass, palmarumycins $\mathrm{C}_{12}$ and $\mathrm{C}_{13}$ yields are shown in Figure 1. Compared to the control without resin addition (CK), the mycelial growth was inhibited or promoted by the resins more or less. Resins HPD100, X-5, AB-8, ADS-17 and DA-201 showed slight enhancement, and resins D1300 
and NKA-9 exhibited slight inhibition on mycelia growth (Figure 1A).

All the resins exhibited obvious enhancing effects on palmarumycin $\mathrm{C}_{12}$ accumulation (Figure $1 \mathrm{~B}$ ). Among them, resin DA-201 was found to be the most effective in enhancing palmarumycin $C_{12}$ production. The highest palmarumycin $\mathrm{C}_{12}$ yields (7.99 $\mathrm{mg} / \mathrm{L}$ and $117.43 \mathrm{mg} / \mathrm{L}$ ) in mycelia and resin were obtained respectively. The total palmarumycin $\mathrm{C}_{12}$ yield reached $125.43 \mathrm{mg} / \mathrm{L}$, which was 62.71-fold as compared with control $(2.00 \mathrm{mg} / \mathrm{L})$. Other effective resins for palmarumycin $\mathrm{C}_{12}$ production included $\mathrm{D}-101$, HPD100, X-5, AB-8, DM130, ADS-17 and S-8.

All the resins exhibited less enhancing effects on palmarumycin $\mathrm{C}_{13}$ production than on palmarumycin $\mathrm{C}_{12}$ production. The palmarumycin $\mathrm{C}_{13}$ yield of the cultures treated with resins D1300, DM130, ADS-17, and NKA-9 was even lower than that of the control without resin addition. Among three resins (HPD100, AB-8 and $D A-201)$ with enhancing effects on palamarumycin $\mathrm{C}_{13}$ production, resin DA-201 was the most effective. When resin DA-201 was applied to the liquid culture of endophyte Dzf12, total palmarumycin $\mathrm{C}_{13}$ yield was increased to $43.44 \mathrm{mg} / \mathrm{L}$, which was 1.41 -fold relative to control (30.73 mg/L) (Figure $1 \mathrm{C})$. Overall, resin DA-201 was found to be the most favorable adsorbent for palmarumycins $C_{12}$ and $C_{13}$ production in Berkleasmium sp. Dzf12 liquid culture, and was used in the subsequent experiments.

\section{Effect of resin DA-201 concentrations on production of palmarumycins $C_{12}$ and $C_{13}$}

The effects of the addition concentrations (1.67, $2.50,3.33,4.17,5.00,5.83$ and $6.67 \%$ ) of resin DA-201 on the palmarumycins $C_{12}$ and $C_{13}$ production in liquid culture of Berkleasmium sp. Dzf12 are presented in Table 2. When the concentration of resin DA-201 addition was increased from 0 to $4.17 \%$, the amount of adsorbed palmarumycins $\mathrm{C}_{12}$ and $\mathrm{C}_{13}$ gradually increased too. The total yields of palmarumycins $\mathrm{C}_{12}$ and $\mathrm{C}_{13}$ reached the highest levels (144.64 and $48.30 \mathrm{mg} / \mathrm{L}$ ) which were 66.34-fold and 1.59fold in comparison with those (2.18 and 30.37 $\mathrm{mg} / \mathrm{L}$ ) of the control, respectively, when resin DA201 was added in the medium at $4.17 \%$ on day 9. There was no significant effect on mycelial growth with resin DA-201 added to the medium at concentrations ranging from 0 to $6.67 \%$ $(\mathrm{g} / \mathrm{mL})$. The mycelia biomass was relatively low when DA-201 resin was added at concentration of $1.67 \%$.

\section{Effect of resin DA-201 addition and incubation time on production of palmarumycins $C_{12}$ and $C_{13}$}

The effects of resin DA-201 addition and incubation period on mycelial growth and production of palmarumycins $\mathrm{C}_{12}$ and $\mathrm{C}_{13}$ are shown in Table 3. When the 11-day-old cultures were treated with resin DA-201 at $4.17 \%$, the total palmarumycins $\mathrm{C}_{12}$ and $\mathrm{C}_{13}$ yields reached the highest values (149.86 and $55.78 \mathrm{mg} / \mathrm{L}$ ), which were 70.69-fold and 1.82-fold of control yield (2.12 and $30.70 \mathrm{mg} / \mathrm{L})$, respectively. From the above results, day 11 was confirmed as the optimal addition time. It allowed a period of 4 days for adsorption. The percentages of palmarumycins $\mathrm{C}_{12}$ and $\mathrm{C}_{13}$ adsorbed in resin DA-201 were 95.81 and $87.20 \%$, respectively. Considering production of the two spirobisnaphthalenes, the highest total yield of palmarumycins $C_{12}$ and $C_{13}$ reached 205.64 $\mathrm{mg} / \mathrm{L}$, which was 6.25-fold higher than for control (32.82 $\mathrm{mg} / \mathrm{L})$, obtained by adding DA-201 resin on day 11 of culture and allowing a period of 4 days for adsorption. As shown in Table 3, if resin DA-201 was added to the cultures early (i.e., the addition time occurred on days 0 and 3 ), it possibly adsorbed more nutrients and thus caused a decrease of palmarumycins $\mathrm{C}_{12}$ and $\mathrm{C}_{13}$ biosynthesis.

\section{DISCUSSION}

The in situ product removal by using macroporous resins in fermentation system is an integrated bioprocess of production and separation. It has many benefits for the overall fermentation process by facilitating the product recovery, eliminating feedback inhibition, overcoming product degradation, avoiding product autotoxicity, reducing cost, and improving the product yield efficiently $[18,19]$. The strategy of employing in situ macroporous resin adsorption has been successfully applied in increasing metabolite yields in some fungal culture systems, such as Fusarium redolens Dzf2 culture for beauvericin production [20], and Hyalodendriella sp. Ponipodef12 culture for botrallin and TMC-264 production [21].

From the results shown in Figure 1B, palmarumycin $\mathrm{C}_{12}$ was undetectable in the broth while it was detectable in the resin and mycelial extracts, which means that palmarumycin $C_{12}$ can be secreted from the intracellular to the 

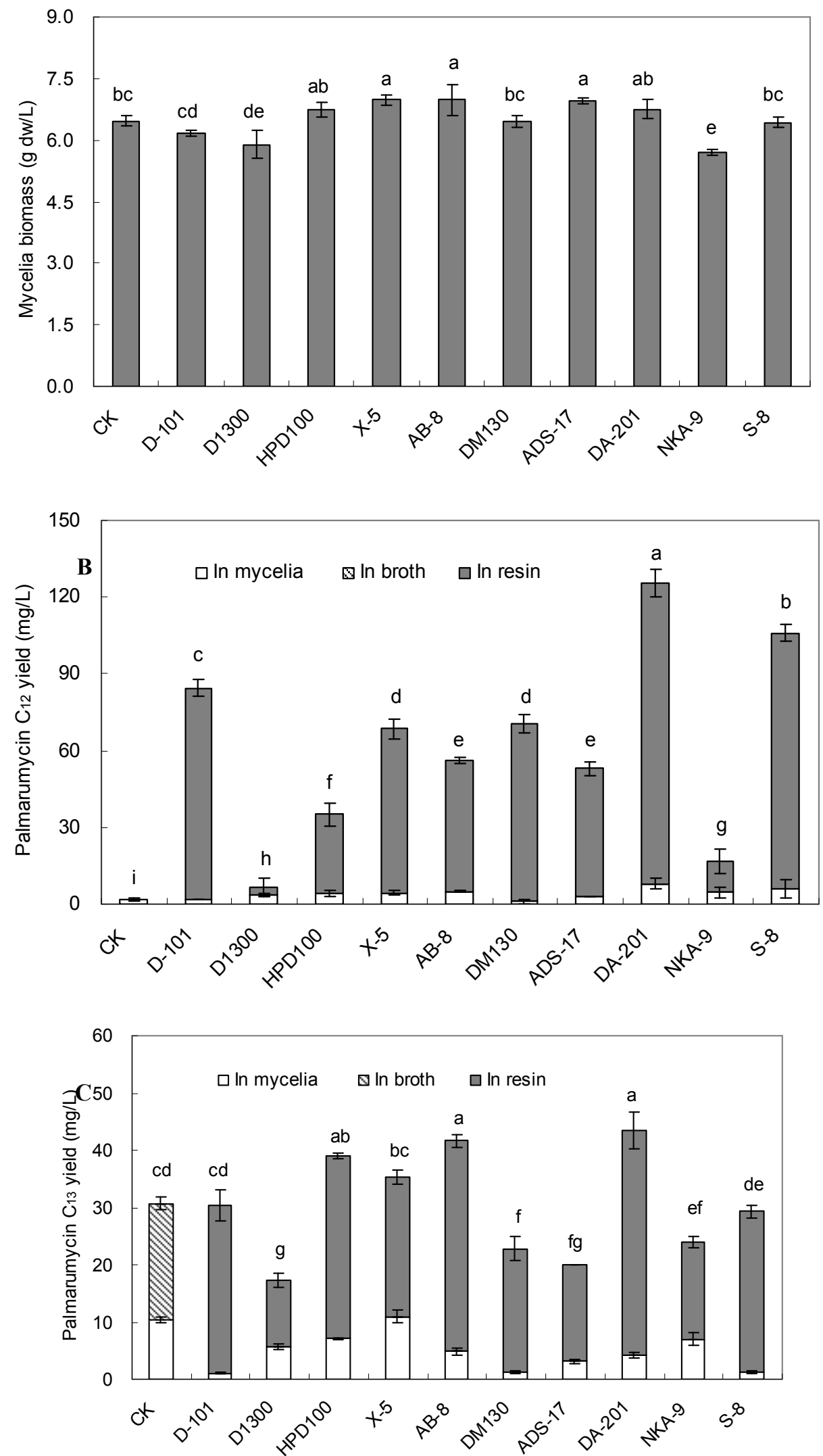

Figure 1: Effects of the resins on mycelia biomass (A), palmarumycin $\mathrm{C}_{12}$ production $(B)$, and palmarumycin $\mathrm{C}_{13}$ production (C) in liquid culture of Berkleasmium sp. Dzf12. CK means without addition of the test resin. Different letters (i.e., a, b, c ...) indicate significant differences among the data of each situation at $P \leq 0.05$. The error bars are standard deviations $(n=3)$ 
Table 2: Effects of resin DA-201 addition concentrations on mycelial growth, palmarumycins $\mathrm{C}_{12}$ and $\mathrm{C}_{13}$ production in liquid culture of Berkleasmium sp. Dzf12

\begin{tabular}{|c|c|c|c|c|c|c|c|c|c|c|}
\hline $\begin{array}{c}\text { Conc. of resin } \\
\text { DA-201 } \\
(\%, g / m L)\end{array}$ & $\begin{array}{c}\text { Mycelia } \\
\text { biomass } \\
\text { (g dw/L) }\end{array}$ & $\begin{array}{c}\mathrm{C}_{12} \text { yield } \\
\text { in mycelia } \\
(\mathrm{mg} / \mathrm{L})\end{array}$ & $\begin{array}{c}\mathrm{C}_{12} \text { yield } \\
\text { in broth } \\
(\mathrm{mg} / \mathrm{L})\end{array}$ & $\begin{array}{l}\mathrm{C}_{12} \text { yield } \\
\text { in resin } \\
(\mathrm{mg} / \mathrm{L})\end{array}$ & $\begin{array}{c}\mathrm{C}_{13} \text { yield } \\
\text { in mycelia } \\
(\mathrm{mg} / \mathrm{L})\end{array}$ & $\begin{array}{c}\mathrm{C}_{13} \text { yield } \\
\text { in broth } \\
(\mathrm{mg} / \mathrm{L})\end{array}$ & $\begin{array}{l}\mathrm{C}_{13} \text { yield } \\
\text { in resin } \\
(\mathrm{mg} / \mathrm{L})\end{array}$ & $\begin{array}{c}\text { Total } \\
\mathrm{C}_{12} \text { yield } \\
(\mathrm{mg} / \mathrm{L})\end{array}$ & $\begin{array}{c}\text { Total } \\
\mathrm{C}_{13} \text { yield } \\
(\mathrm{mg} / \mathrm{L})\end{array}$ & $\begin{array}{c}\text { Total } \mathrm{C}_{12}+ \\
\mathrm{C}_{13} \text { yield } \\
(\mathrm{mg} / \mathrm{L})\end{array}$ \\
\hline 0.00 & $6.42 \pm 0.13^{a b}$ & $2.18 \pm 0.46^{b}$ & $0.00 \pm 0.00^{a}$ & $0.00 \pm 0.00^{\mathrm{e}}$ & $10.50 \pm 0.45^{a}$ & $19.87 \pm 0.86^{a}$ & $0.00 \pm 0.00^{\mathrm{e}}$ & 2.18 & 30.37 & 32.55 \\
\hline 1.67 & $6.09 \pm 0.10^{b}$ & $2.70 \pm 1.07^{b}$ & $0.00 \pm 0.00^{a}$ & $76.43 \pm 5.64^{d}$ & $9.87 \pm 1.60^{\mathrm{ab}}$ & $0.00 \pm 0.00^{b}$ & $28.09 \pm 1.00^{d}$ & 79.13 & 37.96 & 117.09 \\
\hline 2.50 & $6.59 \pm 0.18^{a}$ & $3.31 \pm 1.02^{b}$ & $0.00 \pm 0.00^{a}$ & $92.54 \pm 3.18^{c}$ & $10.82 \pm 1.28^{a}$ & $0.00 \pm 0.00^{b}$ & $32.77 \pm 1.24^{c}$ & 95.85 & 43.59 & 139.44 \\
\hline 3.33 & $6.86 \pm 0.36^{a}$ & $5.34 \pm 1.04^{\mathrm{ab}}$ & $0.00 \pm 0.00^{a}$ & $128.70 \pm 1.12^{b}$ & $7.86 \pm 0.91^{b c}$ & $0.00 \pm 0.00^{b}$ & $39.03 \pm 0.49^{a b}$ & 134.04 & 46.89 & 180.93 \\
\hline 4.17 & $6.61 \pm 0.15^{a}$ & $5.35 \pm 2.46^{a b}$ & $0.00 \pm 0.00^{a}$ & $139.29 \pm 4.86^{a}$ & $5.84 \pm 0.54^{\mathrm{cd}}$ & $0.00 \pm 0.00^{b}$ & $42.46 \pm 2.31^{a}$ & 144.64 & 48.30 & 192.94 \\
\hline 5.00 & $6.66 \pm 0.13^{a}$ & $7.57 \pm 1.04^{a}$ & $0.00 \pm 0.00^{a}$ & $136.03 \pm 1.67^{\mathrm{ab}}$ & $4.36 \pm 1.04^{d}$ & $0.00 \pm 0.00^{b}$ & $39.33 \pm 0.87^{\mathrm{ab}}$ & 143.60 & 43.69 & 187.29 \\
\hline 5.83 & $6.44 \pm 0.25^{\mathrm{ab}}$ & $5.05 \pm 2.01^{\mathrm{ab}}$ & $0.00 \pm 0.00^{a}$ & $136.86 \pm 3.54^{a b}$ & $3.33 \pm 0.76^{d}$ & $0.00 \pm 0.00^{b}$ & $37.60 \pm 2.52^{b}$ & 141.91 & 40.93 & 182.84 \\
\hline 6.67 & $6.51 \pm 0.26^{a b}$ & $5.31 \pm 2.03^{\mathrm{ab}}$ & $0.00 \pm 0.00^{a}$ & $136.12 \pm 4.17^{\mathrm{ab}}$ & $3.30 \pm 1.20^{d}$ & $0.00 \pm 0.00^{b}$ & $37.20 \pm 0.50^{b}$ & 141.43 & 40.50 & 181.93 \\
\hline
\end{tabular}

Notes: The values are expressed as means \pm standard deviations $(n=3)$. Different letters (i.e., $a, b, c, \ldots)$ indicate significant differences among the treatments in each column at $P \leq 0.05$

Table 3: Effects of resin DA-201 addition and incubation time on palmarumycins $\mathrm{C}_{12}$ and $\mathrm{C}_{13}$ production in liquid culture of Berkleasmium sp. Dzf12

\begin{tabular}{|c|c|c|c|c|c|c|c|c|c|c|}
\hline $\begin{array}{c}\text { Addition } \\
\text { time/lncubation } \\
\text { time }(d / d)\end{array}$ & $\begin{array}{c}\text { Mycelia } \\
\text { biomass } \\
\text { (g dw/L) }\end{array}$ & $\begin{array}{c}\mathrm{C}_{12} \text { yield } \\
\text { in mycelia } \\
(\mathrm{mg} / \mathrm{L})\end{array}$ & $\begin{array}{c}\mathrm{C}_{12} \text { yield } \\
\text { in broth } \\
(\mathrm{mg} / \mathrm{L})\end{array}$ & $\begin{array}{c}\mathrm{C}_{12} \text { yield } \\
\text { in resin } \\
(\mathrm{mg} / \mathrm{L})\end{array}$ & $\begin{array}{c}\mathrm{C}_{13} \text { yield } \\
\text { in mycelia } \\
\text { ( } \mathrm{mg} / \mathrm{L})\end{array}$ & $\begin{array}{c}\mathrm{C}_{13} \text { yield } \\
\text { in broth } \\
(\mathrm{mg} / \mathrm{L})\end{array}$ & $\begin{array}{c}\mathrm{C}_{13} \text { yield } \\
\text { in resin } \\
(\mathrm{mg} / \mathrm{L})\end{array}$ & $\begin{array}{c}\text { Total } \\
\mathrm{C}_{12} \text { yield } \\
\text { (mg/L) }\end{array}$ & $\begin{array}{c}\text { Total } \\
\mathrm{C}_{13} \text { yield } \\
\text { (mg/L) }\end{array}$ & $\begin{array}{c}\text { Total } \mathrm{C}_{12}{ }^{+} \\
\mathrm{C}_{13} \text { yield } \\
(\mathrm{mg} / \mathrm{L})\end{array}$ \\
\hline CK & $6.53 \pm 1.08^{a b}$ & $2.12 \pm 0.31^{\mathrm{e}}$ & $0.00 \pm 0.00^{a}$ & $0.00 \pm 0.00^{d}$ & $11.01 \pm 0.53^{a}$ & $19.69 \pm 0.59^{a}$ & $0.00 \pm 0.00^{d}$ & 2.12 & 30.70 & 32.82 \\
\hline $0 / 15$ & $5.14 \pm 0.15^{c}$ & $3.29 \pm 0.34 \mathrm{de}$ & $0.00 \pm 0.00^{a}$ & $77.48 \pm 4.76^{c}$ & $3.14 \pm 0.05^{d}$ & $0.00 \pm 0.00^{b}$ & $10.35 \pm 1.51^{c}$ & 80.77 & 13.49 & 94.26 \\
\hline $3 / 12$ & $5.47 \pm 0.30^{\mathrm{bc}}$ & $4.85 \pm 0.18^{\text {cde }}$ & $0.00 \pm 0.00^{a}$ & $94.46 \pm 3.36^{b}$ & $3.10 \pm 1.02^{d}$ & $0.00 \pm 0.00^{b}$ & $12.94 \pm 2.17^{c}$ & 99.31 & 16.04 & 115.35 \\
\hline $6 / 9$ & $5.86 \pm 0.33^{a b c}$ & $5.82 \pm 1.54^{\mathrm{cd}}$ & $0.00 \pm 0.00^{a}$ & $97.29 \pm 8.30^{b}$ & $4.23 \pm 0.11^{\mathrm{cd}}$ & $0.00 \pm 0.00^{b}$ & $38.35 \pm 1.44^{b}$ & 103.11 & 42.58 & 145.69 \\
\hline $9 / 6$ & $6.33 \pm 0.38^{\mathrm{ab}}$ & $5.85 \pm 1.66^{\mathrm{cd}}$ & $0.00 \pm 0.00^{a}$ & $133.81 \pm 4.10^{a}$ & $6.06 \pm 1.31^{b c}$ & $0.00 \pm 0.00^{b}$ & $41.30 \pm 2.02^{b}$ & 139.66 & 47.36 & 187.02 \\
\hline $10 / 5$ & $6.62 \pm 0.22^{a b}$ & $8.03 \pm 0.63^{b c}$ & $0.00 \pm 0.00^{a}$ & $139.04 \pm 7.75^{a}$ & $6.46 \pm 0.07^{b}$ & $0.00 \pm 0.00^{b}$ & $47.79 \pm 1.74^{a}$ & 147.08 & 54.25 & 193.91 \\
\hline $11 / 4$ & $6.89 \pm 0.47^{a}$ & $10.64 \pm 2.70^{a b}$ & $0.00 \pm 0.00^{a}$ & $139.22 \pm 3.87^{a}$ & $6.34 \pm 1.42^{b}$ & $0.00 \pm 0.00^{b}$ & $49.44 \pm 2.83^{a}$ & 149.86 & 55.78 & 205.64 \\
\hline $12 / 3$ & $6.59 \pm 0.12^{a b}$ & $13.61 \pm 1.09^{a}$ & $0.00 \pm 0.00^{a}$ & $131.97 \pm 4.32^{a}$ & $6.62 \pm 0.61^{b}$ & $0.00 \pm 0.00^{b}$ & $47.95 \pm 1.14^{a}$ & 145.58 & 54.57 & 200.15 \\
\hline
\end{tabular}

Notes: CK, without addition of the test resin. The concentration of resin DA-201 in medium was $4.17 \%(\mathrm{~g} / \mathrm{mL}$ ). The values are expressed as means \pm standard deviations ( $\mathrm{n}=$

3). Different letters (i.e., a, b, $c, \ldots$ ) indicate significant differences among the treatments including addition and incubation time in each column at $P \leq 0.05$ 
extracellular and adsorbed by macroporous resins efficiently. The addition of the resin greatly favored palmarumycin $\mathrm{C}_{12}$ production (Tables 2 and 3 ). $4.17 \%$ of resin DA-201 in the medium is sufficient for achieving the maximal palmarumycins $\mathrm{C}_{12}$ and $\mathrm{C}_{13}$ production from the liquid culture. The yield of palmarumycin $C_{12}$ was increased about 70 fold by addition of resin DA201. It is possible that palmarumycin $C_{12}$ was an intermediate metabolite in the biosynthesis pathway of spirobisnaphthalenes [22]. Addition of resin favored the secretion of palmarumycin $C_{12}$ and suppressed its metabolism into other compounds.

In this study, we just considered three variables by employing macroporous resin adsorption during fermentation such as the type, concentration and addition time of resin. Other variables such as temperature, $\mathrm{pH}$ value, fermentation medium, combination effects of two or more resins, adsorption and desorption kinetics, and bioreactor system for large-scale production by utilizing resin adsorption of palamrumycins $\mathrm{C}_{12}$ and $\mathrm{C}_{13}$ need to be studied in detail [19].

\section{CONCLUSION}

This work is the first, to the best of our knowledge, to report the enhancement of palmarumycins $\mathrm{C}_{12}$ and $\mathrm{C}_{13}$ production using solid-phase adsorption in fungal liquid culture. Among the resins, DA-201 showed the greatest enhancement effect on the accumulation of palmarumycins $\mathrm{C}_{12}$ and $\mathrm{C}_{13}$ in mycelial liquid culture of endophytic fungus Berkleasmium sp. Dzf12. The results indicate that in situ resin adsorption is an effective strategy for enhancing the production of palmarumycins $\mathrm{C}_{12}$ and $\mathrm{C}_{13}$, and also for facilitating their recovery from mycelial liquid culture of Berkleasmium sp. Dzf12.

\section{ACKNOWLEDGEMENT}

This work was co-funded by Hi-Tech R\&D Program of China (no. 2011AA10A202) and National Natural Science Foundation of China (no. 31071710).

\section{REFERENCES}

1. Rodriguez RJ, White JF, Arnold AE, Redman RS. Fungal endophytes: diversity and functional roles. New Phytol 2009; 182: 314-330.

2. Kharwar RN, Mishra A, Gond SK, Stierle A, Stierle D. Anticancer compounds derived from fungal endophytes: Their importance and future challenges. Nat Prod Rep 2011; 28: 1208-1228.

3. Zhao J, Shan T, Mou Y, Zhou L. Plant-derived bioactive compounds produced by endophytic fungi. Mini-Rev Med Chem 2011; 11: 159-168.

4. Kaul S, Gupta S, Ahmed M, Dhar MK. Endophytic fungi from medicinal plants: a treasure hunt for bioactive metabolites. Phytochem Rev 2012; 11: 487-505.

5. Zhou L, Zhao J, Shan $T$, Cai X, Peng Y. Spirobisnaphthalenes from fungi and their biological activities. Mini-Rev Med Chem 2010; 10: 977-989.

6. Cai X, Shan T, Li P, Huang Y, Xu L, Zhou L, Wang M, Jiang $W$. Spirobisnaphthalenes from the endophytic fungus Dzf12 of Dioscorea zingiberensis and their antimicrobial activities. Nat Prod Commun 2009; 4: 1469-1472.

7. Shan T, Tian J, Wang X, Mou Y, Mao Z, Lai D, Dai J, Peng $Y$, Zhou $L$, Wang $M$. Bioactive spirobisnaphthalenes from the endophytic fungus Berkleasmium sp. J Nat Prod 2014; 77: 2151-2160.

8. Schlingmann G, West RR, Milne L, Pearce CJ, Carter GT. Diepoxins, novel fungal metabolites with antibiotic activity. Tetrahedron Lett 1993; 34: 72257228.

9. Krohn K, Michel A, Floerke U, Aust HJ, Draeger S, Schulz B. Palmarumycins C1-C16 from Coniothyrium sp.: Isolation, structure elucidation, and biological activity. Liebigs Ann Chem 1994; 11: 1099-1108.

10. Chu M, Truumees I, Patel MG, Gullo VP, Blood C, King I, Pai JK, Puar MS. A novel class of anti-tumor metabolites from the fungus Nattrassia mangiferae. Tetrahedron Lett 1994; 35: 1343-1346.

11. Thiergardt R, Hug P, Rihs G, Peter HH. Cladospirone bisepoxide-a novel fungal metabolite structure determination. Tetrahedron Lett 1994; 35: 1043-1046.

12. Petersen F, Moerker T, Vanzanella F, Peter $\mathrm{HH}$. Production of cladosporine bisepoxide, a new fungal metabolite. J Antibiot 1994; 47: 1098-1103.

13. Zhao J, Wang $X$, Sun $W$, Mou $Y$, Peng $Y$, Zhou $L$. Medium optimization for palmarumycin $C_{13}$ production in liquid culture of endophytic fungus Berkleasmium sp. Dzf12 using response surface methodology. Electron J Biotechn 2013; 16: DOI: 10.2225/vol16issue6-fulltext-10.

14. Zhao J, Li Y, Shan T, Mou Y, Zhou L. Enhancement of diepoxin $\zeta$ production with in situ resin adsorption in mycelial liquid culture of the endophytic fungus Berkleasmium sp. Dzf12 from Dioscorea zingiberensis. World J Microbiol Biotechnol 2011; 27: 2753-2758.

15. Li Y, Shan T, Mou Y, Li P, Zhao J, Zhao W, Peng $Y$, Zhou L, Ding C. Enhancement of palmarumycin $C_{12}$ and $C 13$ production in liquid culture of the endophytic fungus Berkleasmium sp. Dzf12 by oligosaccharides from its host plant Dioscorea zingiberensis. Molecules 2012; 17: 3761-3773.

16. Li Y, Li P, Mou Y, Zhao J, Shan T, Ding C, Zhou L. Enhancement of diepoxin $\zeta$ production in liquid 
Mou et al

culture of endophytic fungus Berkleasmium sp. Dzf12 by polysaccharides from its host plant Dioscorea zingiberensis. World J Microbiol Biotechnol 2012; 28: 1407-1413.

17. Mou Y, Luo H, Mao Z, Shan T, Sun W, Zhou K, Zhou L. Enhancement of palmarumycins $C_{12}$ and $C_{13}$ production in liquid culture of endophytic fungus Berkleasmium sp. Dzf12 after treatments with metal ions. Int J Mol Sci 2013; 14: 979-998.

18. Schugerl K, Hubbuch J. Integrated bioprocesses. Curr Opin Microbiol 2005; 8: 249-300. 